\title{
US biologists adopt cloning moratorium
}

[WASHINGTON] One of the leading US professional associations of biologists has adopted a voluntary five-year moratorium on the cloning of human beings. But it is also seeking to keep open a window that would allow research on human embryos that might otherwise fall under a wider ban on cloning-related research.

The Federation of American Societies for Experimental Biology (FASEB) last week announced its approval of the moratorium, which had won unanimous approval on 10 September from the federation's public affairs executive committee.

"We want to reassure Americans that biologists have no intentions of cloning human beings," Ralph Yount, president of FASEB and a chemist at Washington State University in Pullman, said in a statement. "Indeed, we would regard cloning a human being as an unethical and reprehensible act."

FASEB has 14 member societies representing more than 52,000 scientists. The moratorium defines "cloning human beings" as "the duplication of an existing or previously existing human being by transferring the nucleus of a differentiated, somatic cell into an enucleated human oocyte, and implanting the resulting product for intrauterine gestation and subsequent birth".

But text accompanying the moratorium makes a point of contrasting cloning intended for implantation and for in vitro research. "We expect that further research using human cells will also be necessary to secure the benefits of insights from animal cloning and nuclear transfer as applied to human health," it states.

In the accompanying statement, FASEB also warns against "imprecise or misused technical language" in planned federal and state legislation. "Such laws could hinder vital biomedical research," it says.

One bill introduced by Representative Vern Ehlers (Republican, Michigan) was amended in July by the House of Representatives Science committee to ban federal funding for the use of cloning for in vitro research in human embryos as well as for producing human beings (see Nature 388, 505; 1997).

Although the FASEB moratorium defends "important new research" in human cells made possible by cloning, officials deny they are taking a stand in favour of human embryo research. The FASEB board "wanted to deal only with" the issue of most concern to the public, which is cloning a new adult human being, says Mike Stephens, a lobbyist for the group. The group's position on human embryo research is "still being discussed by FASEB and its societies", he adds.

Some feel that FASEB may be trying to avoid provoking controversy by steering clear of the heated debate on the ethics of embryo research. "They wanted to reassure the American people without necessarily stirring up other things," says Brigid Hogan, professor of cell biology at Vanderbilt University School of Medicine in Nashville, Tennessee.

Hogan co-chaired a panel on embryo research set up by the National Institutes of Health which concluded in 1994 that such research was acceptable for federal funding if it was carried out within strict limits.

Arthur Caplan, a bioethicist at the University of Pennsylvania, agrees with Hogan. "By omission they are hoping that research on some human clones at the embryo level might be allowed," he said.

FASEB officials also deny that the moratorium is intended to respond to the House Science committee's July vote to outlaw the use of cloning technology for in vitro research on human embryos. "It was really not our goal to affect legislation," says William Brinkley, the group's vice-president, who is dean of the Graduate School for Biomedical Sciences at Baylor College of Medicine in Texas.

Roger Pedersen, a member of FASEB's public affairs executive committee and a reproductive geneticist at the University of California, San Francisco, said that member scientists should be able to use the new cloning technology to do research on human cells in vitro. This, he said, would help scientists understand how adult nuclei are reprogrammed by cellular cytoplasm, possibly opening avenues to novel ways of repairing and regenerating human tissues.

Pedersen led an earlier move by the 2,000member Society of Developmental Biologists (SDB), a FASEB member society, to adopt the moratorium. About a quarter of SDB's members participated in an electronic and mail-in vote on the moratorium in early September; 93 per cent approved it.

In a report to President Bill Clinton in June, the National Bioethics Advisory Commission called on scientific societies to comply voluntarily with a moratorium on federal funding for cloning human beings (see Nature 387, 644; 1997).

Clinton made a similar plea when he announced the moratorium in March (see Nature 386, 97; 1997), and has also drafted legislation outlawing the cloning of human beings for five years. Meredith Wadman

\section{End agreed for ozone-destroying pesticide}

[MONTREAL] More than a hundred countries have agreed to phase out use of the pesticide methyl bromide, which makes a significant contribution to depletion of the ozone layer.

Meeting last week to strengthen the Montreal Protocol, protocol signatories also agreed to try to reduce smuggling of chlorofluorocarbons (CFCs) by adopting licensing and reviewing compliance procedures. Police and customs officials will be given greater powers to intercept illegal imports and exports of ozone-depleting substances.

Methyl bromide is considered to contribute about 10 per cent to the destruction of the ozone layer. Developed countries are responsible for 80 per cent of its use worldwide.

Developed countries will put an end to using methyl bromide by 2005 ; developing countries have an extra 10 years. They will also be eligible to use a C $\$ 25$ million (US\$18 million) fund to help them convert to alternatives to methyl bromide. Canada has contributed C\$5 million to this fund.

Signatories also agreed to find alternatives to CFCs in medicines that release drugs in controlled doses, such as asthmatic inhalers. They will be expected to begin the transition to non-CFC and methyl bromide alternatives by 1999 .

The agreements came on the tenth anniversary of the Montreal Protocol, widely considered the most successful piece of international environmental legislation.

Canada's environment minister, Christine Stewart, welcomed the moves as "a step in the right direction", even though the final outcome fell short of the host country's expectations. Canada had lobbied for earlier deadlines for phasing out methyl bromide 2001 for developed countries and 2011 for the developing world. But Stewart remained upbeat: "We did not get everything we wanted, but the international community did respond, and this agreement is real progress."

Representatives of industry also welcomed the new agreements. But environmentalist groups were more sceptical, and said the commitments fell short of a total and immediate ban on all sales of ozone-depleting substances in the developed world. Friends of the Earth said: "It's more than a disappointment, it's a tragedy for the planet and the integrity of the Montreal Protocol."

Despite the success of the protocol in reducing ozone-depleting substances, global stratospheric ozone continues to decline. The secretary-general of the World Meteorological Organization, G. O. P. Obasi, told the conference of signatories that "during the past 30 days at the beginning of this year's Antarctic ozone decline, more than 30 per cent of the stratospheric ozone over the southern polar region has been destroyed".

David Spurgeon 